\title{
A Concert of Many Tongues
}

\section{Accounting for the Divine Spirit across the Biblical Canon}

This double issue of Pneuma was birthed out of a moment of opportunity in the history of pentecostal biblical scholarship. Across the globe, a generation of pentecostal biblical scholars has generated new layers of scholarship and interpretation of the canonical texts. Over the past several decades, the authors who have contributed to this issue, among others, have provided thick strata of material upon which contemporary pentecostal scholarship of the Scriptures stands. This issue presents a summarizing concert of this material as it locates "The Spirit throughout the Canon: A Survey of Biblical Authors' Approaches to the Divine Spirit." These critical summaries offer up an assembly of biblical scholars from all over the world accounting for the presence and work of the Spirit from Genesis to the Apocalypse.

The idea for this issue was birthed in conversation with Dr. Craig Keener, the F.M. and Ada Thompson Professor of Biblical Studies at Asbury Theological Seminary in Wilmore, Kentucky, USA. He is a generationally significant contributor to New Testament scholarship. Keener's own massive corpus has provided resounding accounts of the presence of the Spirit in the Scriptures, which we do not have the space to recount here. ${ }^{1}$ He conceptualized this issue and called the convocation of pentecostal biblical scholars from across the globe to participate in it. The authors who contributed to this issue are natives of Australia, Canada, Ghana, India, Korea, Nigeria, and the United States of America, and many of them have lived on multiple continents due to their educational and ministry journeys. This project thus represents many of the significant scholarly voices of pentecostal communities from across the world. We acknowledge that there are other important and helpful voices from across the world of pentecostal biblical scholarship that are not represented in this lofty project of providing constructive interpretations of the presence of the Spirit in the canon and the life of the world. The usual constraints of space and time hampered the inclusion of some of these other voices.

1 This can be seen on Keener's faculty page on the Asbury Seminary website (https://asburysem inary.edu/faculty/craig-keener/) as well as his personal website (https://craigkeener.com/). 
As Handel's Messiah narrates the story of Christ in a sequential oratorio, this issue is a series of solos and duets that accounts for the appearance of the divine Spirit throughout the biblical canon. Each of our performers has done so in her or his own voice, in their own style, with their own convictions, and as the fruit of his or her own scholarship. As an academic journal, we have even tried to respect stylistic as well as methodological and substantive differences among our authors.

From the ruach elohim of Genesis 1:2 through the theophanies of the Spirit in the Apocalypse of John, the authors who contributed to this issue resonate with various interpretive strata of pentecostal biblical interpretation. Some of our contributors offer more technical historical-critical interpretations as seen through pentecostal lenses, just as others lean toward biblical theology and theological interpretations of Scripture while still attending to the texts themselves. Keener's invitees thus provide a diversity of approaches as well as backgrounds. Indeed, this special issue of Pneuma is a Pentecost of scholarly voices that celebrate the Holy Spirit.

Owing to the many who contributed to authoring, peer reviewing, and editing this double issue of Pneuma, and the multitude of teachers and students and colleagues who indirectly contributed to this project, this special issue represents one of the best collective and collaborative efforts of Pneuma so far. To all who contributed in any way, we offer our appreciation. Further, to those who will respond, and to the next generation of pentecostal biblical scholars-who will likely represent an even more diverse group, on so many levels, than this one-we offer our encouragement as you forge ahead with the new things of the Spirit of God.

\section{William Oliverio, Jr. and Nimi Wariboko}

